\title{
Swedish shippers' strategies for coping with slow-steaming in deep sea container shipping
}

\author{
Christian Finnsgård ${ }^{1 *}$ (D) Joakim Kalantari ${ }^{2}$, Zeeshan Raza ${ }^{3}$, Violeta Roso ${ }^{4}$ and Johan Woxenius ${ }^{3}$
}

\author{
* Correspondence: christian. \\ finnsgard@sspa.se \\ ${ }^{1}$ SSPA Sweden AB, Chalmers \\ Tvärgata 10, Box 24001, SE-400 22 \\ Gothenburg, Sweden \\ Full list of author information is \\ available at the end of the article
}

\begin{abstract}
When container shipping lines experience over-capacity and high fuel costs, they typically respond by decreasing sailing speeds and, consequently, increasing transport time. Most of the literature on this phenomenon, often referred to as slowsteaming, takes the perspective of the shipping lines addressing technical, operational and financial effects, or a society perspective focusing on lower emissions and energy use. Few studies investigate the effects on the demand side of the market for container liner shipping. Hence, the aim of this study is to elaborate on the logistics consequences of slow-steaming, particularly the strategies that Swedish shippers purchasing deep sea container transport services employ to mitigate the effects of slow-steaming. Workshops and semi-structured interviews revealed that shippers felt they had little or no impact on sailing schedules and were more or less subject to container shipping lines' decisions. The effects of slowsteaming were obviously most severe for firms with complex supply chains, where intermediate products are sent back and forth between production stages on different continents. The shippers developed a set of strategies to cope with the low punctuality of containerised shipping, and these were categorised in the domains of transfer-the-problem, transport, sourcing and distribution, logistics and manufacturing, and product design. All firms applied changes in the transport domain, although the lack of service segmentation limited the effects of the strategy. Most measures were applied by two firms, whereas only one firm changed the product design.
\end{abstract}

Keywords: Container liner shipping, Coping strategies, Slow-steaming, Shippers, Inventory

\section{Introduction}

Shipping lines have reduced sailing speeds to mitigate the effects of over-capacity and, until recently, high fuel costs since the financial crisis started in 2008. Slow-steaming is a rather straightforward issue in the tank and bulk segments, where the shipowner often negotiates terms directly with one or a few shippers. In liner shipping, however, the shipping lines face a vast array of shippers with different preferences for speed and costs; in addition, routes often include multiple port calls, and the ships are engaged in tight and complex itineraries. As a result, timetables are often single-handedly changed, and shippers are merely notified or simply have to wait for shipments to arrive.

(c) The Author(s). 2018 Open Access This article is distributed under the terms of the Creative Commons Attribution 4.0 International License (http://creativecommons.org/licenses/by/4.0/), which permits unrestricted use, distribution, and reproduction in any medium, provided you give appropriate credit to the original author(s) and the source, provide a link to the Creative Commons license, and indicate if changes were made. 
Most of the literature on slow-steaming either takes the perspective of shipowners addressing technical, operational or cost-minimisation issues-assuming that the effect on shippers is fully captured by an increased cost of capital tied up in the transported products-or that of society with implications of lower emissions by slow-steaming. In reality, however, the effects on supply chains using container liner shipping is far more complex; consequently, this study takes the perspective of the shippers. The purpose is to briefly elaborate on the logistics consequences of slow-steaming, categorise principle mitigation strategies, and investigate and categorise the strategies Swedish shippers purchasing deep sea container transport services use to cope with the effects of slowsteaming.

The study started with a workshop aimed at selecting case firms that engage two large forwarders and a set of firms highly dependent on foreign trade. In all, six firms in retailing, steel manufacturing, and industrial systems, equipment and tools were selected for semi-structured interviews conducted by two researchers and a representative from a forwarder. A second workshop with the forwarders and case firms focused on strategies for coping with the effects of slow-steaming in the deep sea container segment.

The first part of the next section reviews literature on slow-steaming and its effects, and the second part elaborates on plausible strategies for coping with the effects of longer lead times. The sections serves as literature review and conceptual framework for the empirical part that follows. It contains a brief section on the Swedish firms' slowsteaming experiences and a more extensive analysis of the mitigation strategies they employ. Finally, implications of the findings are discussed and conclusions drawn.

\section{Slow-steaming and its effects on logistics}

Slow-steaming is the most potent measure for reducing fuel consumption with existing vessels, and it offers shipowners an attractive mix of reduced operational costs, lower external effects and lower vessel capacity on the shipping market. However, the challenge is to keep fulfilling the shippers' quantitative and qualitative needs for maritime transport (Kalantari, 2012). This section focuses on the rationality behind the phenomenon of slow-steaming and its effects.

The negative external effects of shipping and the subsequent need for a substantial reduction of these externalities is increasingly accepted in the maritime community. Energy efficiency, and thereby the reduction of emissions per unit of transport work, can be achieved via a number of operational and technical improvements (Faber et al., 2010; Kontovas \& Psaraftis, 2011a; Notteboom, 2006; Psaraftis \& Kontovas, 2013; Sherbaz \& Duan, 2012); slow-steaming is among the most effective and easiest to implement (Corbett et al., 2009; Cariou, 2011; Faber et al., 2012; Lindstad et al., 2011; Meyer et al., 2012; Psaraftis \& Kontovas, 2010; Tai \& Lin, 2013), and it often comes with a negative $\mathrm{CO}_{2}$ emission abatement cost. Due to the non-linear correlation between speed and fuel consumption (i.e., the so-called admiralty formula, which estimates a cube function, meaning a $10 \%$ speed reduction yields a $27 \%$ fuel consumption reduction), even a marginal speed reduction will result in a substantial fuel consumption reduction (Wang \& Meng, 2012).

Slow-steaming, as a measure for reducing fuel consumption and emissions, is extensively examined in the literature (see, e.g., Mason \& Nair, 2013) and can be divided into 
two categories: (1) the study of the technical validity and quantification of the impact of slow-steaming on ships' fuel consumption and emissions, and (2) the economic viability of this strategy from the shipowners' perspectives, primarily through the study of speed optimisation aimed at cost minimisation or profit maximisation. The first category thoroughly establishes the merits of slow-steaming. The second category, although it offers important insights, approaches slow-steaming more as a supply side reaction to tie up transport capacity, and thus affects the market price for shipping services rather than being an active measure for energy efficiency (Devanney, 2011). This becomes apparent, for instance, when the same body of literature reaches the conclusion of speed increase when market conditions are characterised by relatively low fuel costs, high freight rates and scarce capacity (Psaraftis and Kontovas, 2014), and speed reduction in markets with relatively high fuel prices, low freight rates and over-capacity, as elaborated on by Cariou (2011), Meyer et al. (2012), and Notteboom and Vernimmen (2009).

Although bunker cost savings is a major incentive for slow-steaming, the impact of the fuel price level alone is not as salient as one might suspect because fuel surcharges, or bunker adjustment factor (BAF), distort the economic signal that the fuel price provides to shipowners in regard to sailing speed (ibid). BAF is a contractual construct that transfers the risk of fuel price fluctuations from the shipowner to the shipper. This means that even when fuel prices are extremely high and bunker accounts for more than $60 \%$ of the shipowners total cost (UNCTAD, 2008), the shipowners might opt to retain high speeds as long as the underlying demand for the service is strong (Fransoo \& Lee, 2013; Wang et al., 2011).

Nevertheless, slower speeds result in fewer voyages per year, which essentially reduces the annual transport work produced by the vessel; hence, more ships are required to uphold the frequency of the service (Psaraftis \& Kontovas, 2010). Maximising the utilisation rate of capital intensive and scarce resources is obviously a priority, but in parts of the shipping business cycle, vessel capacity is far from scarce and the option is to lay up ships. Especially for liner shipping, changing the schedule for any reason might create bottlenecks and introduce more variability in the global system, which could create issues that are difficult to foresee (Harrison \& Fichtinger, 2013).

Notwithstanding the positive environmental and economic effects of slow-steaming, the practice also entails significant and potentially negative operational and economic consequences for the shippers, i.e., the customers of the service that the shipping companies produce-most notably, the increased lead time resulting from longer transport times (Fredriksson \& Jonsson, 2009; Maloni et al., 2013; McKinnon, 2012). Unilateral changes in sailing speed contribute positively to the reduction of $\mathrm{CO}_{2}$ emissions, but only temporarily if the supply chains using the service cannot cope with the lead times and opt for more carbon intensive alternatives. Nevertheless, it is feasible that slowsteaming will become the long-term norm due to environmental regulations (Kontovas \& Psaraftis, 2011b), demand pressure or the shipowners' own environmental ambitions. Over the past few years, the demand for environmentally sustainable transportation has amplified and shippers are taking different measures to reduce their negative impact on the natural environment. For instance, IKEA together with its transport providers is striving to minimize its adverse environmental impact, as nearly $80 \%$ of total CO2 emissions of IKEA's business operations are caused by its transportation activities (Lai et al., 2011). Simultaneously, Nike and HP not only reduced emissions from their logistics operations 
but also saved millions of dollars in cost by shifting their shipments from air to sea transport (Gerdes, 2012). Contrary to these initiatives that highlight the best practices pursued by shippers, the empirical research demonstrates that environmental factor is comparatively given less importance by shippers when selecting a transport service. Lammgård (2007) in this context based on a survey conducted in 2003 among Swedish manufacturing and wholesale firms, exhibit that service price, total lead time, reliability, and environmental efficiency of a transport service are respectively the key factors considered in transport service choice decisions. Lammgård and Andersson (2014) in a later survey conducted in 2012 with same target group found that despite the increasing societal concerns about climate challenges, the environmental efficiency of a transport service is consistently considered the least prioritized factor by the Swedish shippers. Moreover, from the French shipper survey (ECHO) of 2004 that covers the properties of 3000 shippers, 10,000 shipments and 20,000 transport chain legs, it could be observed that to deal with demand fluctuations, to enhance production-process' efficiency and not least to reduce warehousing costs, firms are increasingly applying the just in time (JIT) and lean supply chain approaches in their business operations (Guilbault and Gouvernal 2010). Thus, slow steaming as a green argument might not be convincing for shippers, as they prefer shorter lead time and higher reliability over the environment. Additionally, tradeoffs-such as that between sailing speed and punctuality (Harrison \& Fichtinger, 2013) or sailing speed and shelf time, as well as a low rate of waste and obsolescence for perishable goods like fresh food-might warrant fast shipping. Furthermore, slow-steaming increases pipeline inventory and safety stock that is affected by transport time and punctuality. Ronen (2011), however, found evidence that a reduced sailing speed actually increases the punctuality or reliability of the service. This point is contended, in whole or in part, by Harrison and Fichtinger (2013), Maloni et al. (2013), and Saldanha et al. (2009). Regardless of the impact of slow-steaming on service punctuality, there are few authors who have empirically tried to evaluate how the shippers value the trade-off between speed and punctuality.

Notteboom and Rodrigue (2008) contend that shipping lines design their systems to offer a service that is convenient, whereas they are contracted to provide their customers with a service they demand in terms of quality and price. This view, combined with the reasoning above, leads one to conclude that the shipowners are not receptive to any single outside signal to reduce their sailing speed; nor is the shippers' demand on transport time, punctuality, frequency or route a deciding factor for liner shipping companies decisions regarding fleet management. The segmentation of the offered services on the supply side of the market is not sufficient, as shippers are not savvy enough purchasers to make use of a differentiation that exists (Saldanha et al., 2009).

Hence, when fuel prices are high and the market is characterised by overcapacity and, thus, falling freight rates, shipowners implement slow-steaming. Historically, this has been the case any time slow-steaming has been broadly employed in the shipping industry. The reviewed literature reveals a consensus concerning the fact that the adoption of slow-steaming, regardless of how it is communicated and marketed, is motivated by economic factors that arise from temporary market conditions; therefore, the speed increases again once the market characteristics are reversed. 


\section{Shippers' slow-steaming mitigation strategies}

In manufacturing, most parts are procured from domestic suppliers while the strategic parts, which are characterised by a high value and being produced utilising economies of scale, are purchased from other countries (Reeves et al., 2010). Components and sub-assemblies, which also have a low price-to-weight or price-tovolume ratio, are increasingly sourced over longer distances. South Korea, Mexico and Eastern Europe-regular component suppliers to Japan, the USA, Canada and Western Europe, respectively-increasingly face competition from Asia. To a lesser extent, container shipping lines transport products from Europe and the USA to East Asia. In a research review regarding the location aspect of global sourcing strategies, von Haartman and Bengtsson (2015) indicate that most literature is descriptive and predominantly addresses cost advantages and business interactions, a phenomenon also identified by Schiele et al. (2011). Transaction costs (Williamson, 1979) and operational aspects including logistics often seem to be neglected. The phenomenon has attracted substantial scientific attention since then.

According to Deardorff (2005), theories of international trade often assume that transport is costless and instant, or it is simply treated as an add-on. For example, when interviewing Swedish manufacturing firms, Lindau et al. (2004) identified an attitude of treating transport services as "a given infinite commodity available at a market price". This approach is sufficient for selecting hauliers for short distance transport, but much more effort must be spent on inter-continental transport with a large and increasing share of the supply chain's lead times, costs and environmental impacts. Supply chain managers trained and used to solving lead time issues by shortening the length of the chain and send small consignment with road transport. Global supply chains minimising labour costs for each manufacturing step involves true challenges by reintroducing long transport lead times; slowsteaming amplifies these effects.

As mentioned previously, this article aims to identify, structure and analyse the measures for dealing with the increased lead times by slow-steaming. The rendering focuses on components, sub-assemblies and finished products transported by container shipping rather than raw materials transported by bulk shipping. In addition, it focuses on practical and economic issues related to global trade and does not particularly question the trade for environmental reasons, as is done by Tavasszy et al. (2003). When analysing the effects of extended supplier distances, Woxenius (2007) uses logical deduction to suggest a structure of approaches for dealing with the prolonged lead times. The structure is organised along approaches that the supply chain actors can choose from or combine, which are sorted according to the degree of changes in their own operations and the time frame needed for implementation. The set of approaches includes transferring the problem upor downstream, transport, logistics, supply chain structure, manufacturing concept and product design. In the following sections, the structure is used to deal with the increased lead time induced by slow-steaming, with most attention paid to the measures that require the least adaptation from the manufacturing and retailing firms. The structure is found sufficiently fit for the purpose of categorising slowsteaming mitigation strategies because it also addresses longer lead times-but it might not cover all possible actions. 


\section{Coping by transferring the problem up- or downstream}

The simplest, and often the immediate choice for strong actor along the supply chainand often the final assembler or retailer under its own brand-is to keep its own activities as is and require that upstream or downstream actors solve the problems for them, that is, moving the problem along the supply chain rather than solving it. Obviously this reduces the potential benefits. In a more conceptual language, it can be referred to as a channel relationship using transaction cost theory (Coase, 1937; Williamson, 1979, 1981); because the framework will be used to structure discussions with practitioners, the straightforward term transfer-the-problem is used. Taking all the key components of transaction cost theory (i.e. transaction cost, contracting cost, coordination cost and search cost) into account, the total transaction cost of finding solution to the increased lead time caused by slow steaming within the firm itself may be greater than the transaction cost of transferring the problem up or down stream (Coase, 1937), which justifies this phenomenon. From Williamson, $(1981,1979)$ it could be inferred that the supply chain actor that possesses the stronger control over critical resources, in principle, has preferential access to information, which in turn ensures the efficiency and sustainability of its relationship with other supply chain partners. Furthermore, Williamson (1981), illustrates the bilateral exchange relationship from the transactioncost-economizing perspective. The author explains that to meet the unexpected and substantial increase in demand of its closed body cars, and to cut the transportation and inventory costs, General Motors (GM) urged Fisher Body (the body supplier) to relocate its body manufacturing plants close to GM assembly plants. However, upon resistance from Fisher Body, GM made transaction-specific investments and purchased Fisher stock which later resulted into the merger of both firms and facilitated GM operations.

Another example is Volvo Trucks, representating a truly global manufacturing company with brands as Mack, Renault Trucks and UD trucks with a powerful position in the supply chain.. In an example from 2005, 215,000 trucks were manufactured to order with a planning horizon of 19 calendar days. Deliveries of sequenced components and sub-assemblies were very strictly scheduled. Second -tier suppliers were encouraged to produce components in any low-wage country but they had to carry the increased cost of storage and the risk of obsolescence. Batch-delivered parts were often produced and delivered from adjacent regions, but for suppliers with facilities further awaywere forced to store the parts at a pick-up point within a certain time distance set by Volvo.

Hence, Volvo merely moves the problem to its suppliers by defining where they must locate production or distribution centres. Volvo also transfers the risk of obsolescence to its suppliers by buying sequenced and small parts on an assembly plant use basis, i.e. vendor-managed inventory whereas ownership of batch-delivered parts is transferred at pick-up points (Alftrén, 2006).

\section{Coping by changed transport system}

Prolonged lead times by slow-steaming can also be addressed without changing the shipper's operations by replacing container shipping for faster transport. According to Hummels (2001), faster transport services by air and sea reduced the tariffs on 
manufactured cargo from 32\% in 1950 to $9 \%$ in 1998. Between continents, time is generally disproportional to the distance. For manufactured goods, air is sufficiently fast and sea offers large and sufficiently cheap capacity but it is a true challenge to close the supply gap between air and sea in terms of time, cost and capacity. The supply gap can be closed by cutting costs and capacity constraints for air, but absent propulsion technology breakthroughs, together with comparatively high fuel costs and environmental concerns, make it more realistic to improve the speed of sea transport byimproving the port operations, calling fewer intermediate ports, finding new routes, implementing faster vessels and combining traffic modes.

With ever-larger container ships, handling times are considerable, although port operations try to catchup Giving time-critical containers priority during port handling might cut handling time by a day or two but a more likely development is to cut transport time by a number of days when larger flows allow for routing vesselsdirectly between one port in each continent or increase their frequency. So far, however, shipping lines have deployed larger vessels to meet the larger flows .

A potential option is traversing the Northern Sea Route (NSR), which is about 6000 nautical miles-or 50\%-shorter between Northwestern Europe and Northeast Asia than the Suez Canal passage (Raza \& Schøyen, 2014). NSR transit shipping is likely to result in a higher capacity and may ultimately reduce risks of disruption and congestion (Schøyen \& Bråthen, 2011). Nevertheless, literature suggests that the NSR is presently not economically feasible for liner shipping due to shallow waters, a short season and unreliable Arctic ice conditions, extensive building costs for standardised ice-classed vessels, poor infrastructre along the NSR, high and unpredictable NSR tariffs, and a scanty fleet of icebreakers (Furuichi \& Otsuka, 2014; Lasserre, 2014; Lee \& Song, 2014; Liu \& Kronbak, 2010). In addition, the ice-classed ships are more costly, heavier and would consume excessive fuel when used in southern routes during winter (Pierre and Olivier 2015) 2015). Furthermore, the potential reduction in transport time is less significant for China and South Asia, which accounts for a significant share of the current container flows to Europe and a lack of intermediate ports of call along the route also restricts the scope of the NSR.

Nuclear propulsion has been a hope but they have not proven to be of any commercial success (Hass, 2014; Radiationworks, 2015). Nevertheless, there is a technical potential because nuclear-powered aircraft carriers match the size of container giants at 100,000 tons and cruise at up to 35 knots, although at a prohibitive cost (Carlton et al., 2011; DNV, 2014; Gu \& Zhang, 2014). Currently, it is regarded as unrealistic to renew plans for commercial nuclear vessels for both economic and public opinion reasons. Neither significantly increasing speeds with current diesel engine designs nor fitting ships with steam turbines, like the Sea Land Commerce that crossed the Pacific at 33 knots average speed in 1973 (Schoyen and Steger-Jensen, 2017), would be economically justified. However, the potential for new propulsion technology for fast and economical sea transport remains to be seen.

The combination of sea and air, e.g., through Dubai, is regarded as relatively mature, but Mediterranean ports like Trieste and Gioia Tauro in Italy, and Barcelona in Spain, offer a combination of sea and road or rail in order to cut a few days to Northwest Europe, compared to doubling the Iberian Peninsula. Besides reducing lead time, such transport chains avoid passage of the North European and Baltic Sea Sulphur Emission 
Control Area as well as additional costs from using cleaner fuel or emission reduction technology. The inland transport system in China is still slow despite extensive investments in the domestic road and rail network, but when the current investment scheme is finished and operational and administrative routines are improved, hinterland transport times are likely to be reduced significantly. For total transport chains, this can partially compensate for the longer times spent at sea due to slow-steaming.

The Trans-Siberian Railway (TSR) and coming rail alternatives within the Chinese Belt \& Road Initiative are often mentioned as a viable alternative or rather complement to air and sea in regard to time and costs. The TSR is connected to rail tracks in Russia, Belarus, Poland and further in Western Europe, as well as Chinese and Mongolian tracks in Asia. The TSR offers a reduced lead time of nearly 10 days (34\%) between Europe and Asia; for instance, the transport time between Hamburg and Shanghai is 18-20 days compared to 28-30 days via the Suez Canal. The lead time advantage of rail freight is enforced by the slow-steaming of vessels (Rodeman \& Templar, 2014: Verny \& Grigentin, 2009). However, test runs in 2005 for Dynapac, a Swedish manufacturer of construction equipment that imports containers with components from China, resulted in just 2 days to 1 week of lead time reduction at a tripled transport cost compared to sea transport (Wendel, 2005). To speed up transport time, various measures are taken by, e.g., the EU, Russia, Azerbaijan, Kazakhstan and China; these measures include easing border crossings, compatibility in gauges, voltages and safety systems as well as simplifying legal framework and new information and communication technologies (COMCEC, 2017).

For the TSR service operating between Moscow and Shanghai, the total volumes measured in Twenty-foot Equvivalent Units (TEUs) reached 948,000 TEUs in 2008; from this volume, 429,000 TEUs represent international container traffic (Tavasszy et al., 2011.) Currently, the TSR accommodates approximately 5\% of the total shipments between Asia and Europe (Tsuji, 2013). DB Schenker operates weekly train services between Germany and China; 45,000 TEUs were transported by DB Schenker between both countries using the TSR in 2014. Freight rates are up to 50\% higher for TSR over sea transport, but the TSR option between Germany and China is nearly twice as fast as ocean shipment from terminal to terminal (DB Schenker, 2015).

Although the TSR may be competitive in terms of time and costs, there are doubts regarding its capacity. According to the Government of Poland (2004), the capacity of the TSR, after modernisation, is limited to 600,000 TEUs a year compared to the 21,7 million TEUs transited between Europe and Asia in 2015 (UNCTAD, 2016). Hence, container ships will dominate the EU-Asia trade for many years to come, but the TSR is at least an option for reducing the supply gap between sea and air. The TSR can also be instrumental in developing areas along the TSR into sourcing regions for western firms (COMCEC, 2017), with 36 intermodal terminals along the route (Dynkin, 2002).

At present, there are many uncertainties that impair the smooth movement of container cargo between Europe and Asia using the TSR. Among the main issues are cultural and political differences across the countries involved in the TSR, poor cooperation among the railway companies, theft, corruption, and dissimilarities in railway systems in terms of infrastructure, equipment and management. Thus, the use of the TSR for container shipments between East Asia and Western Europe amplifies the cost and lead time compared to other transport modes. Currently, container shipping 
through the Suez Canal is the least expensive option, and the NSR and TSR may appear to be roughly equivalent second-tier alternatives (Cho, 2007; Rodrigue et al., 2013; Song \& Na, 2012; Tavasszy et al., 2011; Verny \& Grigentin, 2009).

\section{Coping by changed sourcing}

The sourcing domain, similar to what (Meixell \& Gargeya, 2005) denotes the supply chain design domain regards which actors are part of the chain and, predominantly, the localisation of the intermediate nodes; more definite locations of suppliers, such as investigated by Eberhardt et al. (2004) and Woxenius (2012); and the localisation of its own plants (Gammeltoft et al. 2010; Radlo 2016). One option is to balance demand over the season and production life cycle by sourcing a specific product from different locations. A manufacturing firm can then order products that matches the lowest forecasted sales volume from distant locations, complementing orders over the season or product life cycle from closer places and emergency orders from suppliers in adjacent countries. With short product life cycles, the first batches of components can be sourced in the relative vicinity of the assembly plants and then sourced from longer distances when the product matures in the market.

A similar distinction is plausible for manfucturing firms sourcing components and sub-assemblies. Generic components are sourced in distant countries and semi-generic products in nearby countries, and successively move the source closer to the assembly facility because the components are more unique. A contradiction is that generic components are often heavy or voluminous products with comparatively low labour content, with small benefits of sourcing in distant low-wage countries involving container shipping.

These measures imply different levels of integration between buyer and seller. Taninecz (2004), for example, finds that firms with the least supplier integration and the most customer integration are less likely to source from China and, thus, be a subject of slow-steaming. He believes that the reason for the latter is just-in-time delivery commitments, but another interpretation is that tight integration means the supplier develops the components, and then the assembly firm simply cannot use another supplier.

\section{Coping by changed logistics and manufacturing concept}

In the logistics and manufacturing domain, an obvious-but often painful-option is surrendering from build to order (Gosling and Naim 2009; Gunasekaran and Ngai 2005; Li and Womer 2012) and rather use prognoses and go back to stock-keeping finished products. In other words, they will make to stock (MTS) (Altendorfer and Minner 2014; Shi et al. 2014) based on forecasts, rather than make to order (MTO) based on customer orders. Buffering components at different stages and applying postponement, i.e., delaying the moment when generic products become specific, might also be an approach for coping with longer lead times caused by slow-steaming. One aspect of logistics involves purchasing transport services, e.g., choosing traffic mode and how to use and combine them based on standard offers as investigated by, for instance, Kiesmüller et al. (2005). Examples are using different traffic modes in different seasons or product life cycles, using air transport for solving occasional problems, and adapting consignment sizes and departure 
frequencies to the transport offer. The current sourcing strategies generally take the supply gap between air and sea into account. Either low-cost, generic products are sent by container shipping or expensive products are sent by air. As a consequence, products with a medium price-weight or price-volume ratio are often not traded between continents. Using the TSR or new offers as part of Belt \& Road Initiative would rather facilitate new trade than taking market shares from sea and air.

\section{Coping by redesigning the product}

In the long run, the product design domain will be further affected by the globalisation of supply chains. The measures include over-delivering, i.e., building with "optional" equipment in the standard model, like the Japanese car manufacturers when they first challenged the manufacturers in Western Europe and the USA. Another way is to modularise the product to decrease the dependency on accurate prognoses (Doran, 2005; Frigant \& Lung, 2002), which the Swedish truck manufacturer Scania realised and mastered. To really reap the benefits of global sourcing, manufacturers are likely to increase the share of generic components, design the product for postponement, or at a minimum decrease the value of unique parts that require local sourcing. Economies of scale in manufacturing also fosters this development. As an example, Japanese producers of electronic calculators used the same electronics in the interior of different calculators in the 1980s-only differentiated by the available buttons on the calculator cover. Drilling extra holes allowed for using all functions also after buying the cheapest model. Another example is Volvo Car Corporation, which only differentiated the V70 models with 140 and $170 \mathrm{hp}$. engines by settings in the engine control software, hence an example of postponement. Another obvious and often commonly cited example is Benetton's dyeing of T-shirts following the sales of the colours in their stores. The conceptual rendering is summarised in the conceptual model in Fig. 1.

Nevertheless, it is a significant simplification that the magnitude of change increases to the right in the figure. For instance, a new product design might imply incremental changes if done consciously between product generations, whereas changing suppliers might imply severe strain on the work in the purchasing department and the punctuality of deliveries will affect the assembly operations. Other measures might not feasible at all; channel relationships are obviously not an option for firms with a weak position in the supply chain, and even strongly positioned firms will pay a price in one way or another.

\section{Empirical findings}

Sweden is a small country that is heavily dependent on foreign trade. About $90 \%$ of the total foreign trade volume is carried by maritime transport in some part of the transport chain (Swedish Maritime Administration (2014). Large parts are transported by dry bulk and tank shipping. Extensive trade with neighbouring countries is dominated by RoRo shipping, but a significant part of the trans-ocean trade is effectuated by container liner shipping. In 2014, the flow through the largest port, Port of Gothenburg, was 837,000 TEUs (Port of Gothenburg, 2015), but feeder shipping via minor Swedish ports as well as rail and road transport directly to and from continental ports accounts for much larger flows. Swedish industry and commerce are therefore heavily dependent on access to effective and efficient maritime transport services. 


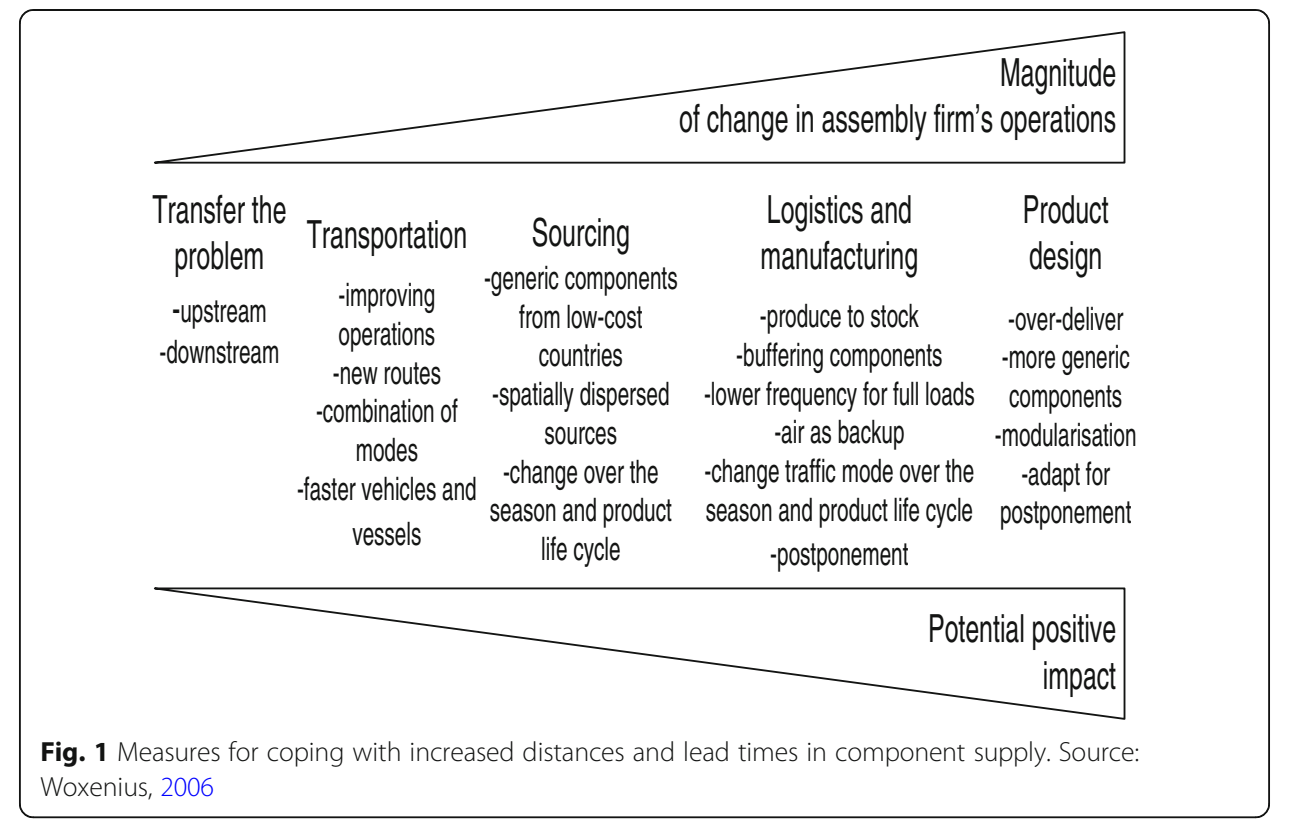

\section{Data collection methodology}

The data collection started with a workshop aimed at selecting case firms among the customers of DB Schenker and DHL, two of the largest active ocean freight forwarders on the Swedish market. Both act globally and are among the largest worldwide. Firms were invited based on their fit to the scope of the study, and larger companies were favoured in the selection because they were assumed to have larger flows of goods and sufficiently mature logistics operations that could deliberately handle the effects of slow-steaming. The firms were represented by senior logistics managers. In all, six firms from different trade-intensive sectors were selected for semi-structured interviews. The selection was based on representation of production strategies MTS, forecasts and MTO, customer orders, and a mix thereof as well as a representation of business-tobusiness (B2B) and business-to-consumer (B2C) sales patterns. Furthermore, the selection was made based on having global supply chains and being available for interviews. The interviews aimed to identify the firms' experience from slow-steaming in deep sea container shipping during the last years; the findings are elaborated on by Finnsgård et al. (2015).

To investigate how firms experience the effects of slow-steaming, a literature review and case selection workshops were used to develop an interview guide. The guide for the semi-structured interviews (appended as Appendix) was developed by two of the researchers and then reviewed and revised by the other researchers involved in the project. The final version was also reviewed by representatives from the forwarders involved in the project. During the entire process, access to multiple analysts and industry representatives was purposefully employed in order to increase the validity of the results. All but one of the interviews were conducted by two researchers, and a representative from the forwarders was present during all interviews. The presence of the latter was regarded as useful because discussions were more lively and detailed than regular researcher-respondent interviews. 
The researchers thus shifted between being active interviewers and observers during the sessions.

The data collected during the interviews was transcribed, processed and sent back to the informants for validation and, in four cases, revised. In all six cases, follow-up interviews were conducted over the telephone or via email. The verified data was stored in a case study database (available on request). The results of the data collection and the analysis were presented and discussed during a workshop attended by all case firms and other project partners for further validation. The main aim of the second workshop, however, was to identify, discuss, and categorise the strategies and measures the case companies have applied to cope with the effects of slow-steaming. Before the second workshop, the respondents reviewed their replies and were exposed to the nomenclature in the shippers' mitigation strategies, as presented in section 3. The results from the case study database, in conjunction with the discussions at the second workshop, resulted in the matrix presented in Table 2.

\section{The case companies and their transport demand}

The case companies can be divided based on production strategy, i.e., if they apply MTS or MTO. MTS companies deliver their products to final consumers off the shelf from warehouses or retail locations, meaning that the lead time gap is maximally expanded. This entails that any changes to the lead time do not necessarily impact the customer lead time. This is in contrast to MTO companies, for which any increase in transit lead time proportionally impacts the customers' lead time. Data are summarized in Table 1.

Company A is a global retailer with 147,000 employees that contributes to a turnover of 29 billion $€$ in 2014. In Sweden, Company A has 19 retail locations, employs roughly 13,000 workers, and sold for 1.46 billion $€$ in 2014. Company A claims to provide sustainably produced and distributed, affordable products that are available in the company's own stores and under its own brand. The company sources its products globally, and $90 \%$ of the total volume moved by trans-ocean liner shipping includes finished products from manufacturing sites directly to stores or via distribution centres.

Table 1 Data for the case companies

\begin{tabular}{|c|c|c|c|c|c|c|c|c|}
\hline \multirow[t]{2}{*}{ C. } & \multirow{2}{*}{$\begin{array}{l}\text { Turnover, } \\
\text { M€ } \\
\text { Globally } \\
\text { (SE) }\end{array}$} & \multirow{2}{*}{$\begin{array}{l}\text { Presence in } \\
\text { No. of } \\
\text { Countries }\end{array}$} & \multirow{2}{*}{$\begin{array}{l}\text { Employees } \\
\text { Globally (SE) }\end{array}$} & \multicolumn{2}{|c|}{$\begin{array}{l}\text { Share of } \\
\text { Volume }\end{array}$} & \multirow{2}{*}{$\begin{array}{l}\text { Annual Flow, } \\
\text { TEU } \\
\text { Globally (SE) }\end{array}$} & \multirow{2}{*}{$\begin{array}{l}\text { Through } \\
\text { Forwarder }\end{array}$} & \multirow[t]{2}{*}{ Incoterms } \\
\hline & & & & MTS & MTO & & & \\
\hline$A$ & $\begin{array}{l}29,000 \\
(1460)\end{array}$ & 27 & $\begin{array}{l}147,000 \\
(13000)\end{array}$ & $100 \%$ & & 500,000 & Yes, partly & FCA \\
\hline B & 290 & 61 & 1700 & & $100 \%$ & $500(400)$ & Yes & DAP \\
\hline C & 750 & 75 & 1700 & & $\begin{array}{l}80- \\
100 \%\end{array}$ & 10,000 & No & $\mathrm{CIF}$ \\
\hline $\mathrm{D}$ & 720 & 28 & 5000 & $100 \%$ & & $2500(1800)$ & Yes & FOB, FCA \\
\hline $\mathrm{E}$ & $\begin{array}{l}40,000 \\
(3360)\end{array}$ & 100 & $\begin{array}{l}150,000 \\
(9000)\end{array}$ & & $\begin{array}{l}80- \\
100 \%\end{array}$ & $30,000(3000)$ & Yes & $\begin{array}{l}\text { EXW, FOB, DAP, } \\
\text { CPT }\end{array}$ \\
\hline $\mathrm{F}$ & $\begin{array}{l}9250 \\
(1860)\end{array}$ & 130 & $47,500(7000)$ & $30 \%$ & $70 \%$ & 6000 & Yes & CPT \\
\hline
\end{tabular}

SE Sweden; Incoterms, CIF Cost Insurance and Freight, CPT Carriage Paid To, DAP Delivery at Place, EXW Ex Works, FCA Free Carrier, FOB Free On Board 
Raw material and components are often locally sourced to the manufacturing facilities, hence, the small share of container shipping in the first links of the supply chain. Products are ordered based on sales prognoses and MTS. Company A's logistics organisation is not involved in sourcing decisions in the short term; therefore, it only fulfils the transport demand induced by the purchasing organisation. In the medium term, 23 years, the logistics organisation does influence decisions to strategically reconfigure the sourcing patterns. Air freight is used in cases of unforeseen emergencies but almost never as a part of the base case supply plan. Once product demands are forecasted and ordered, the logistics organisation purchases A to B transport, as opposed to door-todoor transport. Suppliers deliver according to Incoterm FCA (Free Carrier). As an example, the assignment to deliver goods to port, haul the goods port-to-port, and the final delivery from destination port and the store or warehouse could be purchased separately as well as from different service providers. Therefore, the control needed to optimise the distribution system rests in the hands of the logistics organisation. The supply chain can be characterised as functional and strives to fill whole units in order to boost efficiency. The company's annual global maritime volumes are estimated at 500,000 TEUs, which are mainly composed of 40-ft high cube containers.

Company B is an industrial equipment manufacturer and distributor of industrial filtration, recycling and cleaning equipment in workshop environments. The company has sales and service presence in 31 countries, manufacturing and assembly plants in 11, and distributors in an additional 30 countries. The company has an annual turnover of $290 \mathrm{M} €$ and employs some 1700 people. Almost two-thirds of the volume is transported by truck and RoRo shipping to continental Europe, and the remaining third is shipped out by containerised liner shipping. The flows included in the case study are the outbound volumes of finished products and components from Sweden to the Far East and North and South America. Air transport is used as a competing mode to maritime transport but the products are voluminous, making them expensive to send by air. For cost and environmental reasons, the aim is to minimise the use of air freight. Both components and finished products are produced after Company B receives actual orders. The level of customisation for many of the systems sold is such that orders normally originate from sales agents or offshore manufacturing sites, which in turn also place their orders based on actual end-customer orders. Sales are delivered according to Incoterm DAP (Delivered at Place). Transport services are routinely purchased as door-to-door transport from a forwarder. The company has a standing order based on the departure schedule of the shipping lines. Deviation from the standing order is managed through contacts with a forwarder. The forwarder is biannually re-evaluated in competitive tendering. The annual volumes for the relevant flows are about 500 TEUs.

Company $\mathrm{C}$ is a manufacturer of steel powder products. It turns over $750 \mathrm{M} €$ per annum, employs around 1700 workers, and has sales and distribution representation in 75 countries. Most of the production is located in Sweden from Swedish iron ore, but there are also production facilities in the USA and India. Company $\mathrm{C}$ recognizes that its global competitive advantage is product quality and advanced research and development. Flows included in the case study are outbound flows of components (i.e., general steel powder) and finished products (i.e., customer-specific prepared mixes of steel powders). The company purchases container liner shipping services directly, without 
the involvement of a forwarder, using Incoterm CIF (Cost Insurance and Freight) when delivering to its customers. The company has a standing order based on the departure schedule of the relevant shipping lines. Deviation from the standing order is managed through contacts with the shipping line. Air freight is an option only during rare occasions of emergency. Usually, different shipping lines are called on in order to manage variation in demand and disturbances. Transport service suppliers are reevaluated annually using competitive tenders. The annual volume for the relevant flows is about 10,000 TEUs.

Company D is a fashion retailer with 480 stores in Europe. The company identifies its value proposition as delivering an affordable fashion experience that is more feminine, inspiring, joyful and sustainable. Key product ranges are women's wear, kids' wear and cosmetics. Company D also operates an online sales channel to customers in all EU countries and Norway. The company has some 5000 employees worldwide and turns over roughly $720 \mathrm{M} €$ annually. About $80 \%$ of the volume is managed through a distribution centre in Sweden, and the inbound flow to this facility is what is considered in the case study. Aside from 3 to $4 \%$ of the total volume, which is shipped using air freight, the inbound flows are shipped by containerised liner shipping, usually in the East Asia to Europe trade. Supply is delivered according to Incoterms FOB (Free on Board) and FCA (Free Carrier). The bulk of the orders are made based on sales forecasts, and additional orders are placed based on point of sales data. The transport service is purchased from a forwarder who coordinates the transport door-to-door. This means that ensuring access to capacity and matching demand with supply regarding the transport is part of the service purchased. The annual volume for the relevant flows is about 2500 TEUs.

Company $\mathbf{E}$ is an industrial systems and equipment manufacturer with a diverse product range, from industrial power systems and robotics to low voltage products and automated process systems. Globally, the company is present in 100 countries, has 300 manufacturing locations, 150,000 employees and a turnover of approximately 40 billion $€$. In Sweden, the company employs 9000 people in 30 different locations. As such, the company has multifaceted supply chains with both complex inbound and outbound flows for MTS and MTO. It is estimated that, based on volume, MTS dominates, whereas measured in value, MTO is the dominating strategy. Considering palletised goods, the ratio of inbound to outbound volume is 60/40. Local manufacturing sites predominantly serve local markets, which makes the inbound flows of interest for this case study. However, the product range is so diverse that any one characterisation of the flows is bound to be inaccurate in some sense. The company controls and optimises its own flows by purchasing A to B transports. Supply is delivered according to Incoterms EXW (Ex Works) and FOB, and deliveries using DAP and CPT (Carriage Paid To). The logistics organisation does not influence the supply strategy and acts as an internal supplier of transport, given the demand derived from the manufacturing and purchasing functions. One of the objectives of the logistics organisation is to increase the level of central control over the physical flows to and from the many sites at different geographical locations. The centralised control and coordination aims to increase the efficiency of the physical flow of goods within the company's supply and distribution networks. 
Company $\mathbf{F}$ is an industrial materials and tools manufacturer with expertise in materials technology and a range of products, including industrial tooling equipment for mining, machining solutions to advanced materials, and construction equipment. The company is organised in five business divisions. Globally, the company employs 47,500 and has an annual turnover of 9.25 billion $€$. The company identifies its strategic strength as a technology leader in the premium segment of its sector-a segment characterised by high entry barriers. The division included in this case study is the materials technology division, which employs around 7000 people in Sweden. It produces advanced steel materials for further manufacturing by its customers and has an annual turnover of 1.5 billion $€$. The significant flows in the case are movement back and forth between offshore production sites and final distribution to customers. A common supply chain starts with products made in Sweden, which are shipped to their own production sites in China, then back to Sweden for final adaptation before being shipped out to the final customer. In the case of a final customer in China, the products in various manufacturing stages are shipped between continents several times, which obviously amplifies the impact of transport lead time. Deviation in lead time can also impact the levelling of production in production facilities in cases of MTO products. About $30 \%$ of the orders can be delivered directly from stock, whereas 70\% are MTO. The transport services are purchased via a forwarder with regular allotments that are booked in advanced and modified if necessary. The Incoterm CPT (Carriage Paid To) is used. The company aims to control the flow from origin to destination, meaning that one way or another, the liner shipping leg of any transport always falls within the purview of the company. The transport lead time is a significant portion of the total lead time, which means that, especially for the MTO segment, its impact on the customers' lead time is substantial. The annual volumes for the relevant flows are about 6000 TEUs.

\section{Effects of slow-steaming as perceived by the shippers}

The first phase of this exploratory case study aimed to understand how shippers are affected by the widespread application of slow-steaming, which is analysed and presented by Finnsgård et al. (2015). The reduction of sailing speed since 2008-2009 has resulted in $20-50 \%$ longer transport times for the shippers in this study, depending on trade and whether transport time is considered port-to-port or door-to-door, or for single legs from A to B or for entire global supply chains. The price of the service has, as perceived by the shippers, at best decreased marginally or stagnated/increased marginally at worst. The trade-off between price and speed was uniformly considered unfavourable. Most of the studied companies were prepared to pay more for faster transits, with one company finding the trade-off more complex than just price and speed. However, even this company did not view the current trade-off as favourable. All the case companies more or less confirmed that they did not experience any increase in punctuality after the introduction of slow-steaming. Some of the companies could also confirm, based on their experience as shippers, that the shipping lines offering the highest service frequency also generally delivered a service with higher punctuality. This is not so much due to lack of deviations, e.g., missed or cancelled departures, 
delays etc.; rather, the impact of any disturbance was minimised due to the higher frequency of the service.

Companies applying MTS deliver their products to final consumers off the shelf from retail locations, meaning that the lead time gap is maximally expanded. This entails that any changes to the lead time do not necessarily impact the customer lead time. The literature review led to the hypothesis that the increase in lead time would lead to an increase in inventory, most notably pipeline inventory but also safety stock, which would increase inventory costs. Surprisingly, all but one company stated that any increase in inventory cost was a secondary concern, as the revenue side of the business was the deciding factor. For companies applying MTS, availability in store (avoiding loss of sales) and obsolescence (price cuts due to overstocking) were deemed more of a concern than increases in pipeline and safety stock costs. As for companies applying MTO, where any increase in transit lead time proportionally impacted the end customers' lead time, the risk for loss of sales or decreased customer service due to excessive lead time was a bigger issue. Only one company identified the increased inventory cost as a major issue. This company's production structure was such that a product, which is made to order, would be shipped by liner shipping between facilities several times during a production cycle, amplifying the impact of sailing speed on lead time and inventory cost several fold. This was also the only company that prioritised a minimised transport time above all else. They calculated a price tag for each container and day, meaning that it was clear what they would be willing to pay to reduce the lead time. Otherwise, the division was between MTS and MTO companies, where MTS companies valued punctuality more and MTO companies put a higher value on speed. This is understandable because the customers of MTS companies are usually not directly affected by transit lead time due to the expanded lead time gap; therefore, the companies valued the ability to operate according to plan with minimal deviation more than making plans with shorter cycle times. Conversely, for MTO companies, any additional day in transit meant an additional day of lead time for their customers; hence, they found a higher value in the ability to deliver in a timely fashion.

The environmental benefits by the increased energy efficiency are highlighted in the slow-steaming literature. However, none of the companies in this study recognised slow-steaming as an explicit measure for increased environmental performance. Although no one disputed the reduction in fuel consumption and greenhouse gas emissions resulting from slow-steaming, the individual companies saw vastly different potentials in their customers' willingness to bear the additional costs. MTS companies that retail fashion and home furnishing products to consumers perceived a higher demand for increased environmental performance. Conversely, the MTO companies that had other industrial companies as customers noted that any cost associated with surpassing their customers explicitly stated requirements regarding environmental performance was likely to be viewed unfavourably. Therefore, the distance to consumers was decisive for the level of environmental concerns. Furthermore, they also pointed out that there is a limit to how much the lead time to a customer can increase before they starts looking for other, even qualitatively inferior, substitutes. This could lead to a paradox where the increase in energy efficiency in shipping that comes at the cost of prolonged transport time would lead to a modal shift to faster modes with dramatically larger energy use. 


\section{Shippers' strategies for managing the consequences of slow-steaming}

The case companies use a number of strategies for managing the longer transport times following the reduction of sailing speed. These strategies and their application by the case companies are elaborated on and divided into the principle lines of action as follows:

\section{Transfer-the-problem}

Although all of the case companies could claim to employ this to some extent, only two consciously employ transfer-the-problem as a strategy for managing the increasing lead times. In the case of Company F, which regards outbound flows in an MTO setting, the customers, or downstream actors, simply have to accept the lead time offered. The liner shipping market does not offer enough segmentation in its service offering to make this approach effective. Of course, changing modes of transport is an option, and both companies also utilise the available tools in the transport domain, but the cost of changing modes to, e.g., air freight, is prohibitively high.

For Company A, which operates in an MTS setting and mostly handles inbound flows, the transference is made upstream to its suppliers. There are limitations regarding this strategy, but the power dynamic and large complex network of suppliers still make this approach a viable option in this case.

\section{The transport domain}

All case companies identify this strategy as their primary effort for managing the increasing lead times. This is intuitively plausible, as this is the most immediate action that can be taken-in an extreme case, by changing modes to a faster one. However, in light of the spatial configuration of sources and sinks, the distances in question generally make air freight the only feasible substitute. This is beside the issue regarding capacity; it is prohibitively expensive. This is evident in the fact that only marginal flows are transported by air in all of the companies, and almost none of the volumes that are flown were planned to do so originally, i.e., air freight is only used as a "firefighting" measure.

However, in the current market, there are significant limits to what can be achieved through this measure. All companies cite the lack of segmentation in the supply of shipping services. It appears that once the sailing speeds drop on a specific trade, it does so across the board and for all available services. This means that there aren't very many choices to be made by the transport buyers in terms of transport time. Most of the companies re-evaluate their service contracts regularly via competitive tenders and monitor the performances of their service providers continuously, but the differences between the different providers are not large enough to make up for the real increase in transport time that has taken place during the past years. In reality, the buyers are able to choose between competing shipping lines with regard to price and punctuality, but not transport time. Even in the case of punctuality, the companies maintain that the discrepancy between the level of service they ideally would like to purchase and what is offered is too large.

Several of the companies control their flow of goods in their physical network by purchasing individual legs of the transport chain separately. This potentially creates an opportunity to improve the lead time performance by optimising routing and planning as well as some of the operations, but very little can be exerted from these types of measures in the studied cases. 


\section{The sourcing domain}

Companies D and E utilise management of the sourcing domain as a means to handle the increasing lead times that follow slow-steaming. Both companies' inbound flows are included in this case study. For Company E, where the flows regard components and raw materials to manufacturing facilities that are primarily meant to serve a local market, this entails not only choosing a supplier with regard to location, but also choosing the type of components that would allow the mitigation of lead time effect by inventory management. As elaborated above, the materials flow system and supply and distribution network of Company D is more diverse and complex; it is not able to be expressed in such simplistic division. However, it was clear during the interviews and workshops that sourcing domain management was one of two general strategies utilised for handling lead time increases.

Company D, which is a fashion retailer, already utilises the sourcing domain to manage seasonality and the different segments of their product range. Aside from the transport domain in the medium to long term, choice of suppliers based on location is the only viable solution because the company does not manufacture the products sold under its own brand nor does it purchase its entire product range from sub-suppliers.

The two principle differences between the two companies that deliberately use the sourcing domain strategy is that one (D) operates according to MTS and handles a flow of finished products, and the other (E) purchases components and raw materials and operates according to MTO. This means that where the former's choices are limited to supplier location, the latter can add an additional aspect of inventory management and choice of components in its efforts. This is something that is already a feature of the MTS system, but not of the MTO system if it is assumed that components are not kept in stock.

\section{The logistics and manufacturing domain}

Both companies that utilise measures that can be categorised in the logistics and manufacturing domain handle outbound flows in an MTO setting. This makes one of the most potent options of this domain irrelevant, i.e., producing to stock. Both companies apply postponement and produce their products closer to their customers. By doing so, the most time-consuming part of the transport chain is moved upstream, and the stocks of inventory can be shifted from high-value finished products to components and raw materials. The lead time gap is therefore expanded by keeping local stock of the necessary input materials to satisfy the demands of the markets closer to the facilities.

There are two different problems with this approach for the different companies. Company B, though a leader in its segment, has a growth-by-acquisition strategy. This has historically meant that the capability overlap between its facilities at different locations is not large enough for this strategy to be enough on its own in the short-tomedium term. Many of the products can only be produced at a certain facility, and in some cases, the overlap that exists is not properly spatially dispersed. This is likely due to the fact that the primary reason for acquisition has not been to reduce lead time, but to gain market shares and/or capabilities in other segments rather than existing ones.

For Company $\mathrm{C}$, the problem is the market perception of the different facilities. Although there is a certain disparity in quality between the more established facilities and the newer offshore ones, the market perception of these differences are 
disproportionate, resulting in order specifications in regard to where the ordered products are to be produced. If this issue can be satisfactorily resolved, this approach could prove to be very effective for reducing lead times.

\section{The product design domain}

Only Company $\mathrm{C}$ has utilised changes in the product design domain, to an extent of any consequence, as a measure for reducing lead time. The design of the final product has been modified so that a wide range of different products can be assembled locally based on a handful of generic components, hence fostering postponement. This change in design allows the company to expand the lead time gap by producing and shipping components to different markets ahead of actual orders, which reduces customer lead time. During the workshop, the other companies present could not identify a product range in their market offering that could feasibly be redesigned in such a manner.

The strategies and combinations of strategies that the case companies currently use, or see as likely to employ in the foreseeable future, are summarised in Table 2.

\section{Concluding remarks}

Slow-steaming, i.e., the practice of reducing sailing speed, is periodically adopted by trans-ocean liner shipping companies. During periods where the market is characterised by low demand, high fuel prices, low freight rates and over-capacity, they tend to unilaterally reduce the speed of the service they offer. The latest instance in which this has occurred is in the period following the 2008-2009 global financial crisis, and the speeds have not yet rebounded to pre-crisis levels. Most of the existing research regarding slow-steaming is from the fields of maritime engineering and maritime economics, meaning that the phenomenon is studied from the ship owners' perspectives in the technical, operational and economics domains.

The shippers, i.e., the buyers of the maritime services, have garnered very little attention from the research community, even though their systems bear the grunt of the consequences of drastically shifting the properties of the services available. In this exploratory case study, the answers to the questions of how the shippers' systems are affected by the widespread application of slow-steaming and how shippers manage these consequences are sought. To do so, a multiple case study consisting of six Swedish multi-national companies has been undertaken. The case study is based on data collected from interviews, seminars and workshops, secondary data, and literature reviews.

The case companies use a number of strategies in order to manage the increase in transport time. All try to reduce the lead time, or at least increase its punctuality, by monitoring transport service suppliers and regularly re-evaluating them by open

Table 2 Summary of case company strategies for managing increasing transit lead time

\begin{tabular}{llllll}
\hline Case company & Transfer-the-problem & Transport & Sourcing & Logistics and manufacturing & Product design \\
\hline A & $X$ & $X$ & & \\
B & $X$ & $X$ & $X$ & \\
C & $X$ & & & \\
D & $X$ & $X$ & & \\
E & $X$ & $X$ & & \\
F & $X$ & $X$ & & & \\
\hline
\end{tabular}


competitive tenders. However, the lack of segmentation in the market offering from the service providers was identified as a major obstacle for the efficacy of this strategy. Even companies that are willing to pay substantially more for a higher quality liner shipping service are basically faced by a mode choice and then between modes at either end of the transport time and price scales, rather than a choice between shipping lines or forwarders.

Two of the companies also approach this challenge by transfer-the-problem upor downstream. This means, in the case of the inbound flows of an MTS company, that the suppliers are tasked with minimising their delivery times; in the case of an MTO company's outbound flow, the customer needs to accept the longer lead times. The inbound flow of two other companies, one operating according to MTS and the other to MTO, approach this issue in the sourcing domain. By selecting suppliers that are geographically closer or sourcing generic components so as to expand the lead time gap, they try to mitigate the impact of slower sailing speeds on the lead time. The outbound flow of two other companies, both MTO, take on this challenge in the logistics and manufacturing domain. This is achieved largely by locating production facilities closer to the markets they supply in order to reduce the lead time to their customers. Finally, one of the companies also aims to reduce lead time by redesigning their product range so as to be able to assemble a large range of products from a handful of generic components. This enables the company, which delivers its products according to MTO, to expand the lead time gap by stocking production facilities closer to markets with generic components based on sales forecasts. As a final note, this paper aimed at contributing in the field of supply chain management and logistics rather than economics.

\section{Appendix}

Interview guide

Questionnaire Slow-Steaming Logistics - <Company $><$ date $>$

The purpose of this study is to explore how the shippers' manage consequences of slow-steaming maritime transport services in their supply chains. The interview will start with a very short recap of the project, the project partners, financial backers and the purpose of the project. The interview guide and questions will be in English; however, the questions and answers will be in Swedish. The researchers performing the interview will shortly present themselves.

Time, date and place:

Interviewers: $<$ Interviewer1 $>(<$ Company $>)$, $<$ Interviewer2 $>(<$ Company $>)$

Q1: Could you introduce us with a brief presentation of yourselves and your roles in your organization?

Q2: Confidentiality. We have to discuss the issue of confidentiality. This is a scientific project with the aim to publish the results in a scientific journal. This area, slowsteaming, is by research standards a relatively new phenomenon; how companies address this phenomenon is even more so. We would like to be open with the case companies that we are interviewing in this study. We have no special agenda to reveal secrets about our interviewees in our publications-we are only trying to address our purpose.

Q3: Describe your company and business area. 
Q4: Local or global? Size (turnover/employees)? Growing/decreasing? Market share?

Q5: What type of flow of goods does your company have? Current state-history?

Q6: Do you use trans-ocean shipping?

Q7: What do you ship in or out? Current state-history?

Q8: Do you supply your processes or distribute out to customers or processes? (different segments?)

Q9: MTS or MTO?

Q10: Customer order point?

Q11: Import/export?

Q12: What delivery terms do you use (or accept)? EXW, DDP, DDA, DDU

Q13: How far ahead do you need to secure (book) trans-ocean shipping?

Q14: Do you overbook trans-ocean shipping? (to be certain of capacity)

Q15: Do you have scheduled (fixed) bookings for trans-ocean shipping? (long-term or short-term deals)

Q16: Do you speculate (spot-trade) in trans-ocean shipping?

Q17: What are your terms for cancelling trans-ocean shipping?

Q18: What happens with cancelled departures or if your cargo missed the departure?

Q19: How do you define lead time?

Q20: How do you define through-put time?

Q21: Have changes in either lead time or through-put time affected manufacturing planning and control/inventory management/purchasing/distribution?

Q22: Have changes in either lead time or through-put time affected purchasing?

Q23: Have you noticed the phenomenon "slow-steaming"? If so, how?

Q24: When did this happen (that you noticed slow-steaming)? Was there a specific moment in time?

Q25: How did you notice it?

Q26: Why did you notice it?

Q27: Did you (or could you have) affect(ed) the change? Did you want/need/prefer to?

Q28: Can you now affect the speed of your trans-ocean shipping?

Q29: Would you be willing to pay additionally for a decreased sailing time for transocean shipping?

Q30: Would you consider it favorable to choose the sailing speed for trans-ocean shipping?

Q31, How do you choose service providers? How do you purchase these services? (A2B/system).

Q32: Have you modified your supply-distribution-storage-structure in any way (according to slow-steaming)?

Q33: Have modifications of your supply chains been different in the long or short term?

Q34: Has slow-steaming affected your offering to the market? (services, delivery precision, etc.)

Q35: Increased costs due to slow-steaming. Have you noticed an increase in your supply chain costs that you can refer to slow-steaming in trans-ocean shipping? If so, how could you determine this, and have you followed it closely?

Q36: Are there trade-offs for your company regarding lead time, frequency, punctuality, transport cost and total cost? Comment on each. 
Q37: What requirements do you have on your supply chains (trans-ocean shipping in particular)?

Q38: How did you end up with these requirements? How did they evolve? (aware, happened, are no, etc.)

Q39: Who controls the requirements? How are production, logistics and purchasing connected in this aspect?

\section{Acknowledgements}

This research was funded by the Swedish Maritime Administration.

\section{Authors' contributions}

All authors have contributed to the writing of the paper. All authors have read and approved the final manuscript.

\section{Competing interests}

The authors declare that they have no competing interests.

\section{Publisher's Note}

Springer Nature remains neutral with regard to jurisdictional claims in published maps and institutional affiliations.

\section{Author details}

${ }^{1}$ SSPA Sweden AB, Chalmers Tvärgata 10, Box 24001, SE-400 22 Gothenburg, Sweden. ${ }^{2}$ VTI - Swedish National Road and Transport Research Institute, Teknikringen 10, Box 55685, SE-10215 Stockholm, Sweden. ${ }^{3}$ University of Gothenburg, Box 610, SE-405 30 Gothenburg, Sweden. ${ }^{4}$ Chalmers University of Technology, SE-412 96 Gothenburg, Sweden.

Received: 12 September 2017 Accepted: 7 May 2018

Published online: 23 May 2018

\section{References}

Alftrén, H. (2006). Future logistics strategy of Volvo truck corporation, Chalmers logistics update. 2 February

Altendorfer K, Minner S (2014) A comparison of make-to-stock and make-to-order in multi-product manufacturing systems with variable due dates. IIE Trans 46(3):197-212

Cariou P (2011) Is slow-steaming a sustainable means of reducing CO2 emissions from container shipping? Transp Res Part D Transp Environ 16(3):260-264

Carlton JS, Smart R, Jenkins V (2011) The nuclear propulsion of merchant ships: aspects of engineering, science and technology. J Mar Eng Technol 10(2):47-59

Cho, J-K (2007) The Eurasian land-bridge and its impact on global logistics. Journal of Transportation Management 18(2): 38-50

Coase RH (1937) The nature of the firm. Economica, New Series 4(16):386-405

COMCEC (2017) Improving transnational transport corridors in the OIC member countries: concepts and cases, standing Committee for Economic and Commercial Cooperation of the Organization of the Islamic Cooperation Coordination Office, Ankara

Corbett JJ, Wang H, Winebrake JJ (2009) The effectiveness and costs of speed reductions on emissions from international shipping. Transp Res Part D Transp Environ 14(8):593-598

Deardorff A (2005) The importance of the cost and time of transport for international trade in ECMT time and transport. European conference of ministers of transport, round table 127, Paris

Devanney J (2011) Are owners and charterers really that stupid? In: Center for Tankship Excellence http://www.c4tx.org/ ctx/pub/stupid.pdf, accessed 2015-10-14

DNV GL. (2014). Alternative fuels for shipping. Strategic Research \& Innovation position paper 1. Available at http:// www.dnv.com/. Accessed 2015-09-23

Doran D (2005) Supplying on a modular basis an examination of strategic issues. Int J Phys Distrib Logist Manage 35(9/ 10):654-663

Dynkin, B. (2002). Comments on the regional railroad network and power grid interconnection. Second workshop on power grid interconnection in Northeast Asia. Shenzhen, China, may 6-8

Eberhardt M, Mclaren J, Millington A, Wilkinson B (2004) Multiple forces in component localisation in China. Eur Manag J 22(3):290-303

Faber, J., Freund, M., Köpke, M. \& Nelissen, D. (2010). Going slow to reduce emissions - can the current surplus of maritime transport capacity be turned into a opportunity to reduce GHG emissions? Seas at risk, delft, Seas at Risk

Faber J, Nelissen D, Hon G, Wang H, Tsimplis M (2012) Regulated slow-steaming in maritime transport - an assessment of options, costs and benefits. CE Delf, Delf

Finnsgård, C., Kalantari, J., Roso, V., \& Woxenius, J. (2015). Slow-steaming from the shippers perspective. I-NUF Conference, Long Beach, 21-23 October

Fransoo JC, Lee C-Y (2013) The critical role of ocean container transport in global supply chain performance. Prod Oper Manag 22(2):253-268

Fredriksson A, Jonsson P (2009) Assessing consequences of low-cost sourcing in China. Int J Phys Distrib Logist Manage 39(3):227-249

Frigant V, Lung Y (2002) Geographical proximity and supplying relationships in modular production. Int J Urban Reg Res 26(4):742-759 
Furuichi, M. Otsuka, N (2014) Economic feasibility of finished vehicle and container transport by NSR/SCRcombined shipping between East Asia and Northwest Europe. Proceedings of the IAME 2014 Conference. Norfolk, USA

Gammeltoft P, Pradhan JP, Goldstein A (2010) Emerging multinationals: home and host country determinants and outcomes. Int J Emerg Markets 5(3/4):null

Gerdes, J. (2012) How Nike, Wal-Mart and IKEA Save Money and Slash Carbon by Shipping Smarter Forbes, 24 February

Gosling J, Naim MM (2009) Engineer-to-order supply chain management: a literature review and research agenda. Int J Prod Econ 122(2):741-754

Government of Poland (2004). Euro-Asian links activities related to the development of Euro-Asian transport links. UN Economic and Social Council, Working Party on Transport Trends and Economics. 20-21 September

Gu Y, Zhang C (2014) An evaluation of alternative energies or fuels for future deep sea container shipping. Masters Thesis, University of Gothenburg

Guilbault M, Gouvernal E (2010) Transport and logistics demand: new input from large surveys of shippers in France. Transp Res Rec J Transp Res Board 2168:71-77

Gunasekaran A, Ngai EWT (2005) Build-to-order supply chain management: a literature review and framework for development. J Oper Manag 23(5):423-451

Harrison A, Fichtinger J (2013) Managing variability in ocean shipping. Int J Logist Manage 24(1):7-21

Hass BS (2014) Strategies for the success of nuclear powered commercial shipping. In: Report submitted to Connecticut maritime association http://atomicinsights.com/wp-content/uploads/CMA-Nuclear-Paper_Benjamin-Haas-3.pdf. Accessed 2015-09-26

Hummels D (2001) Time as a trade barrier. GTAP working paper no. 18, Purdue University

Kalantari, J. (2012). Foliated transportation networks - Evaluating feasibility and potential. Technology Management and Economics. PhD Thesis, Chalmers University of Technology. Gothenburg, Sweden

Kiesmüller GP, de Kok AG, Fransoo JC (2005) Transportation mode selection with positive manufacturing lead time. Transp Res Part E Logist Transp Rev 41(6):511-530

Kontovas C, Psaraftis HN (2011a) The link between economy and environment in the post-crisis era: lessons learned from slow-steaming. Int J Dec Sci Risk Manage 3(3/4):311-326

Kontovas C, Psaraftis HN (2011 b) Reduction of emissions along the maritime intermodal container chain: operational models and policies. Marit Policy Manag 38(4):451-469

Lai K-H, Lun V-Y-H, Wong C-W-Y, Cheng T-C-E (2011) Green shipping practices in the shipping industry: Conceptualization, adoption, and implications. Resources, Conservation and Recycling 55(6): 631-638.

Lammgård C (2007) Environmental perspectives on marketing of freight transports - the intermodal road-rail case. PhD. University of Gothenburg, Gothenburg

Lammgård C, Andersson D (2014) Environmental considerations and trade-offs in purchasing of transportation services. Res Transp Bus Manage 10(supplement C):45-52

Lasserre, F (2014) Case studies of shipping along Arctic routes. Analysis and profitability perspectives for the container sector. Transp Res Part A: Policy and Practice 66: 144-161

Lee S-W, Song J-M (2014) Economic possibilities of shipping though Northern Sea route. Asian J Ship Logist 30(3):415-430

Li H, Womer K (2012) Optimizing the supply chain configuration for make-to-order manufacturing. Eur J Oper Res 221(1):118-128

Lindau, R., Woxenius, J., \& Edlund, P. (2004). Verkstadsindustrins logistik - en innovationssystemanalys the logistics of the manufacturing industry - an innovation system analysis. Meddelande 120, Department of Logistics and Transportation, Chalmers University of Technology, Göteborg. In Swedish

Lindstad H, Asbørnslett BE, Strømman AH (2011) Reductions in greenhouse gas emissions and cost by shipping at lower speeds. Energy Policy 39(6):3456-3464

Liu M, Kronbak J (2010) The potential economic viability of using the Northern Sea route NSR as an alternative route between Asia and Europe. J Transp Geogr 18(3):434-444

Maloni M, Paul JA, Gligo DM (2013) Slow-steaming impact on ocean carriers and shippers. Mar Econ Logist 15(2):151-171

Mason R, Nair R (2013) Supply-side strategic flexibility capabilities in container liner shipping. Int J Logist Manage 24(1):22-48

McKinnon AC (2012) The possible contribution of the shipper to the decarbonisation of deepsea container supply chains. Logistics Research Network Conference, Cranfield

Meixell MJ, Gargeya VB (2005) Global supply chain design: a literature review and critique. Transp Res Part E Logist Transpo Rev 41(6):531-550

Meyer J, Stahlbock R, Voß S (2012) Slow-steaming in container shipping. In: System science (HICSS), 2012 45th Hawaii international conference on Maui, pp 1306-1314

Notteboom T (2006) The time factor in liner shipping services. Mar Econ Logist 8(1):19-39

Notteboom T, Rodrigue J-P (2008) Containerisation, box logistics and global supply chains: the integration of ports and liner shipping networks. Mar Econ Logist 10(1-2):152-174

Notteboom T, Vernimmen B (2009) The effect of high fuel costs on liner service configuration in container shipping. J Transp Geogr 17(5):325-337

Pierre C, Olivier F (2015) Relevance of the Northern Sea route (NSR) for bulk shipping. Transp Res Part A Policy Pract 78(supplement C):337-346

Port of Gothenburg (2015). Port of Gothenburg in short: http://www.portofgothenburg.com/. Accessed 2015-10-07

Psaraftis HN, Kontovas CA (2010) Balancing the economic and environmental performance of maritime transportation. Transp Res Part D: Transp Environ 15(8):458-462

Psaraftis HN, Kontovas CA (2013) Speed models for energy-efficient maritime transportation: a taxonomy and survey. Transp Res Part C: Emerg Technol 26:331-351

Psaraftis HN, Kontovas CA (2014) Ship speed optimization: concepts, models and combined speed-routing scenarios. Transp Res Part C Emerg Technol 44(supplement C):52-69

Radiationworks (2015). Nuclear powered ships: www.radiationworks.com/nuclearships.htm. Accessed 2015-10-14

Radlo, M.-J., 2016. Evolutionary view of international production fragmentation in enterprises, Offshoring, Outsourcing and Production Fragmentation: Linking Macroeconomic and Micro-Business Perspectives. Palgrave Macmillan UK, London, pp. 127-152 
Raza Z, Schoyen H (2014) The commercial potential for LNG shipping between Europe and Asia via the Northern Sea route. J Mar Res 11(2):67-79

Reeves KA, Caliskan F, Ozcan O (2010) Outsourcing distribution and logistics services within the automotive supplier industry. Transp Res Part E Logist Transp Rev 46(3):459-468

Rodemann H, Templar S (2014) The enablers and inhibitors of intermodal rail freight between Asia and Europe. J Rail Transp Plan Manage 4(3):70-86

Rodrigue J-P, Comtois C, Slack B (2013) The Geography of Transport Systems. 3rd Edition Routledge, New York

Ronen D (2011) The effect of oil price on containership speed and fleet size. J Oper Res Soc 62(1):211-216

Saldanha JP, Tyworth JE, Swan PF, Russell DM (2009) Cutting logistics costs with ocean carrier selection. J Bus Logist 30(2):175-195

DB Schenker (2015). DB Schenker develops the Eurasian land bridge. DB Schenker homepage. Available at http://www.deutschebahn.com/. Accessed 2015-09-25

Schiele H, Horn P, Vos B (2011) Estimating cost-saving potential from international sourcing and other sourcing levers: relative importance and trade-offs. Int J Phys Distrib Logist Manage 41(3):315-336

Schøyen H, Bråthen S (2011) The Northern Sea route versus the Suez Canal: cases from bulk shipping. J Transp Geogr 19(4):977-983

Schoyen H, Steger-Jensen K (2017) Nuclear propulsion in ocean merchant shipping: The role of historical experiments to gain insight into possible future applications. J Clean Prod 169:152-160

Sherbaz S, Duan W (2012) Operational options for green ships. J Mar Sci Appl 11(3):335-340

Shi X, Shen H, Wu T, Cheng TCE (2014) Production planning and pricing policy in a make-to-stock system with uncertain demand subject to machine breakdowns. Eur J Oper Res 238(1):122-129

Song J-Y, Na H-S (2012) A Study on the Intercontinental Transportation Competitiveness Enhancement Plan between Northeast Asia and Europe Using the Trans-Siberian Railway. International Journal of Engineering and Technology 4(2): 208-212.

Swedish Maritime Administration (2014) Omvärldsbevakning av Forskning \& Innovation inom sjöfartsområdet 2013/ 2014 (Monitoring Research \& Innovation in the Shipping Domain 2013/2014), Swedish Maritime Administration, Report No. 15051-0, Norrköping. In Swedish

Tai H-H, Lin D-Y (2013) Comparing the unit emissions of daily frequency and slow-steaming strategies on trunk route deployment in international container shipping. Transp Res Part D Transp Environ 21:26-31

Taninecz G (2004) Partially made in China. Industry Week 253(10):31-32

Tavasszy L, Minderhoud M, Perrin JF, Notteboom T (2011) A strategic network choice model for global container flows: specification, estimation and application. J Transp Geogr 19(6):1163-1172

Tavasszy LA, Ruijgrok CJ, Thissen MJPM (2003) Emerging global logistics networks implications for transport systems and policies. Growth Change 34(4):456-472

Tsuji H (2013) Competitive advantages and disadvantages of trans-Siberian railway route - case study of Korea and Japan. Int J Railway 6(4):139-147

UNCTAD (2008) Review of maritime transport 2008. UNCTAD, New York and Geneva

UNCTAD (2016) Review of maritime transport 2016 - the long-term growth prospects for seaborne trade and maritime businesses. UNCTAD, United Nations conference on trade and development, New York and Geneva

Verny J, Grigentin C (2009) Container shipping on the Northern Sea route. Int J Prod Econ 122(1):107-117

Von Haartman R, Bengtsson L (2015) The impact of global purchasing and supplier integration on product innovation. Int J Oper Prod Manage 35(9):1295-1311

Wang DH, Chen C-C, Lai C-S, Lai C-L (2011) The rationale behind and effects of bunker adjustment factors. J Transp Geogr 19(4):467-474

Wang S, Meng Q (2012) Sailing speed optimization for container ships in a liner shipping network. Transp Res Part E Logist Transp Rev 48(3):701-714

Wendel, R. (2005). Logistics manager, Dynapac Compaction Equipment Interview 23 September

Williamson OE (1979) Transaction-cost economics: the governance of contractual relations. J Law Econ 22:233-261

Williamson OE (1981) The economics of organization: the transaction cost approach. Am J Sociol 87(3):548-577

Woxenius J (2006) Temporal elements in the spatial extension of production networks. Growth Change J Urban Reg Policy 37(4):526-549

Woxenius J (2007) Challenging the lead time issues in global supply chains. In: Lalwani C, Mangan J, Butcher T, Mondragon A (eds) C. Proceedings of the Logistics Research Network Annual Conference 2007, 5-7 September. University of Hull, Kingston upon Hull. pp 183-188

Woxenius J (2012) Directness as a key performance indicator for freight transport chains. Res Transp Econ 36(1):63-72 